\title{
Candida auris: epidemiological situation, laboratory capacity and preparedness in the European Union and European Economic Area*, January 2018 to May 2019
}

Diamantis Plachouras ${ }^{1}$, Felix Lötsch ${ }^{1}$, Anke Kohlenberg ${ }^{1}$, Dominique L Monnet ${ }^{1}$, the Candida auris survey collaborative group ${ }^{2}$

1. European Centre for Disease Prevention and Control (ECDC), Stockholm, Sweden

2. The members of the Candida auris survey collaborative group are listed at the end of the article

Correspondence: Diamantis Plachouras (Diamantis.Plachouras@ecdc.europa.eu)

Citation style for this article:

Plachouras Diamantis, Lötsch Felix, Kohlenberg Anke, Monnet Dominique L, the Candida auris survey collaborative group . Candida auris: epidemiological situation, laboratory capacity and preparedness in the European Union and European Economic Area*, January 2018 to May 2019. Euro Surveill. 2020;25(12): pii=2000240. https://doi.org/10.2807/1560-7917.ES.2020.25.12.2000240

Article submitted on 04 Mar 2020 / accepted on 10 Mar 2020 / published on 26 Mar 2020

Between January 2018 and May 2019, 349 cases of Candida auris were reported in the European Union/ European Economic Area*, 257 (73.6\%) colonisations, 84 (24.1\%) bloodstream infections, seven (2.0\%) other infections and one case of unknown infection/colonisation status (0.3\%). Most cases (97.1\%, $\mathrm{n}=339$ ) were reported from Spain or the United Kingdom, but also for the first time in Greece, the Netherlands and Poland. Laboratory capacity and preparedness has improved since January 2018.

Candida auris is an emerging pathogenic fungus that is causing difficult-to-control outbreaks of invasive healthcare-associated infections associated with patient carriage and environmental surface contamination. In 2018, the European Centre for Disease Prevention and Control (ECDC) performed a survey to assess the situation regarding C. auris epidemiology, control measures and laboratory capacity for detection in the European Union/European Economic Area (EU/ $E E A) *[1]$. The information from this survey was used to increase awareness about $C$. auris and to assess the need for further action to support C. auris detection, prevention and control activities in EU/EEA countries. In order to assess the evolution of the epidemiological situation and the current state of preparedness in the EU/EEA, the ECDC conducted a similar survey in 2019.

\section{Survey}

In June 2019, we invited the national focal points in EU/ EEA countries to complete an online survey. The focal points or their deputies are nominated experts who collaborate with the ECDC on healthcare-associated infections. This survey was an update of the 2018 survey and consisted of 14 questions, four on the country's epidemiological situation, six on laboratory capacity and four on preparedness and response. A case was defined as a patient in whom $C$. auris was detected irrespective of whether it was an infection or carriage.

\section{Epidemiological situation}

We received replies from 29 of 30 EU/EEA countries. In total, nine countries reported 349 cases from 1 January 2018 to 31 May 2019. Cases were reported from Spain $(n=291)$, the United Kingdom (UK) $(n=48)$, Germany $(n=3)$, the Netherlands $(n=2)$, Austria $(n=1)$, France $(n=1)$, Greece $(n=1)$, Norway $(n=1)$ and Poland $(n=1)$. Bloodstream infections accounted for 84 (24.1\%) cases, other infections for seven (2.0\%) cases and carriage for $257(73.6 \%)$ cases (Figure 1). Information on infection or carriage status was missing in one case (0.3\%). Fifteen EU/EEA countries reported that they did not detect any case of $C$. auris infection or carriage in the given period. No answer was received from the Czech Republic. Five countries (Latvia, Lithuania, Luxembourg, Portugal and Romania) reported that information on the detection of cases of $C$. auris infection or carriage was not available at the national level.

Among the cases, 324 (92.8\%) were locally acquired, 19 (5.4\%) were considered imported because they had a history of hospitalisation in a country with reported cases, and for six (1.7\%) cases the place of acquisition was unknown. Among the 19 imported cases from January 2018 to May 2019, eight were imported from India, four from Kenya, two from Qatar and one each from Kuwait, Oman, Pakistan, South Africa and the United Arab Emirates. Figure 2 summarises the geographical distribution of $C$. auris cases in EU/EEA countries and the reported origin of imported cases for the period January 2013 to May 2019.

Between January 2013 and May 2019, two countries reported local transmission in hospitals: Spain $(n=2$ hospitals) and the UK ( $n=6$ hospitals). All these hospitals were large tertiary care centres in large cities. Inter-facility transmission was reported in both Spain and the UK. At the time of the survey in June 2019, there was ongoing transmission in two hospitals in Spain. 
Reported cases of Candida auris infection and carriage, EU/EEA, January 2013-May $2019(\mathrm{n}=969)$

A. Number of cases by year and type of infection or carriage

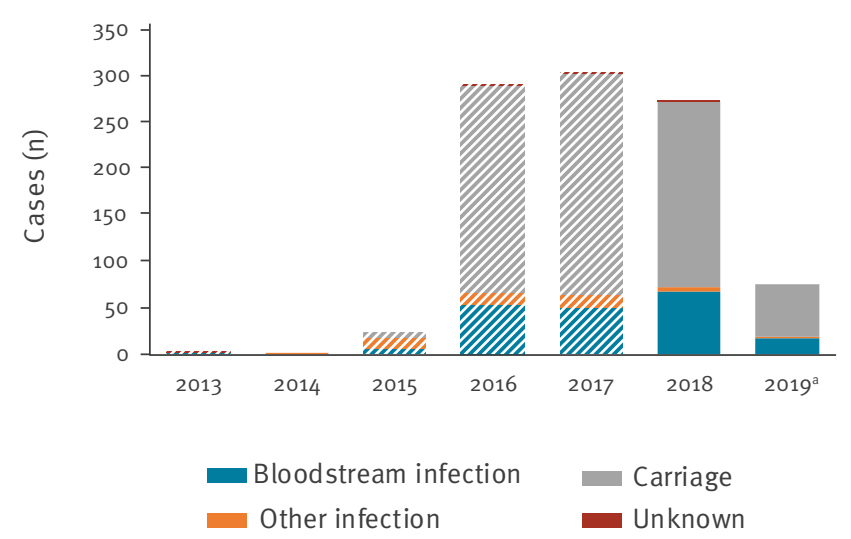

a 2019 data until May.

EEA: European Economic Area; EU: European Union.

Dashed bars indicate that data are from the previous survey.

\section{Laboratory capacity}

Twenty-two of the 29 responding EU/EEA countries reported the presence of a reference laboratory for $C$. auris. In all but one of the reference laboratories, antifungal susceptibility testing was available (Table). Methods for the identification of $C$. auris were available, including MALDI-TOF in 22 countries, sequencing of $D_{1}$ / D2 locus in eight countries and sequencing of internal transcribed spacer in seven countries. Guidance for laboratory testing was available in 13 countries.

\section{Public health preparedness and response}

At the time of the survey, infection with or carriage of $C$. auris was notifiable in only five EU/EEA countries (Finland, France, Greece, Ireland and Italy) (Table), but 11 other countries (Croatia, Cyprus, Estonia, Hungary, Lithuania, Luxembourg, Norway, Portugal, Romania, Slovakia and Slovenia) were considering making $C$. auris a notifiable disease. Guidance for the clinical management of $C$. auris as well as guidance for infection control was available in seven countries and 11 countries, respectively. In six countries, retrospective surveillance was ongoing, whereas prospective surveillance was performed in 10 countries. In 2018, clinical and laboratory alerts were issued in 11 and 17 countries, respectively.

\section{Discussion}

Candida auris is an emerging Candida species causing bloodstream and other infections, mostly in severely ill patients with serious underlying medical conditions. It has been detected on five continents within a few years of its first identification in 2009. Identification of $C$. auris requires specialised laboratory methodology such as matrix-assisted laser desorption/ionisation-time of
B. Number of imported cases $(n=26)$

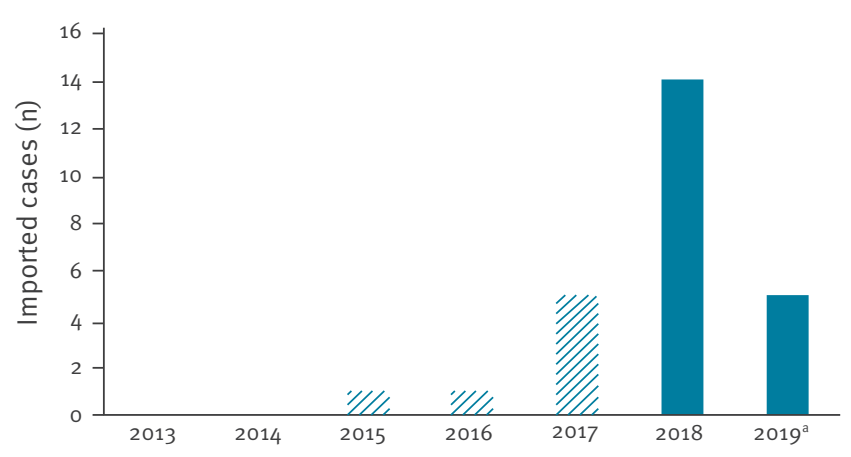

flight (MALDI-TOF) mass spectrometry or sequencing of specific gene loci $[2,3]$. Reliance on traditional methods may lead to misidentification. Candida auris is usually resistant to fluconazole [4] and has been associated with resistance to multiple antifungal drug classes including echinocandins and amphotericin B [5]. The case fatality of bloodstream infections with $C$. auris has been reported to be up to $60 \%$ and the infections may be difficult to treat because of resistance to multiple antifungal agents [2,6]. Candida auris is able to colonise surfaces and survive outside the host [7] and unlike other Candida species, C. auris has been linked to outbreaks in healthcare settings. These characteristics render $C$. auris a potential threat for European healthcare facilities.

The number of new cases in 2018 in the EU/EEA $(n=273)$ was comparable to those in 2016 and $2017(n=290$ and 303 , respectively) [1]. However, three countries (Greece, the Netherlands and Poland) reported cases for the first time in 2018. After completion of this survey, one case of $C$. auris infection was reported in Italy in September 2019 [8], thus increasing the number of EU/EEA countries that have so far detected cases to 10.

In European countries outside the EU/EEA, one case of colonisation with previous hospitalisation in Spain was reported in Switzerland in 2017 [9] and a hospital outbreak affecting 49 critically ill patients was reported in Russia in 2016 and 2017 [10]. In the EU/ EEA, hospital outbreaks have occurred in Spain and the UK, as already reported in the 2018 survey [1], with spread between hospitals documented in both countries. All other countries that identified cases of $C$. auris only reported sporadic cases and did not detect 
Geographical distribution and reported origin of Candida auris infection and carriage, EU/EEA, January 2013-May 2019 $(\mathrm{n}=26)$

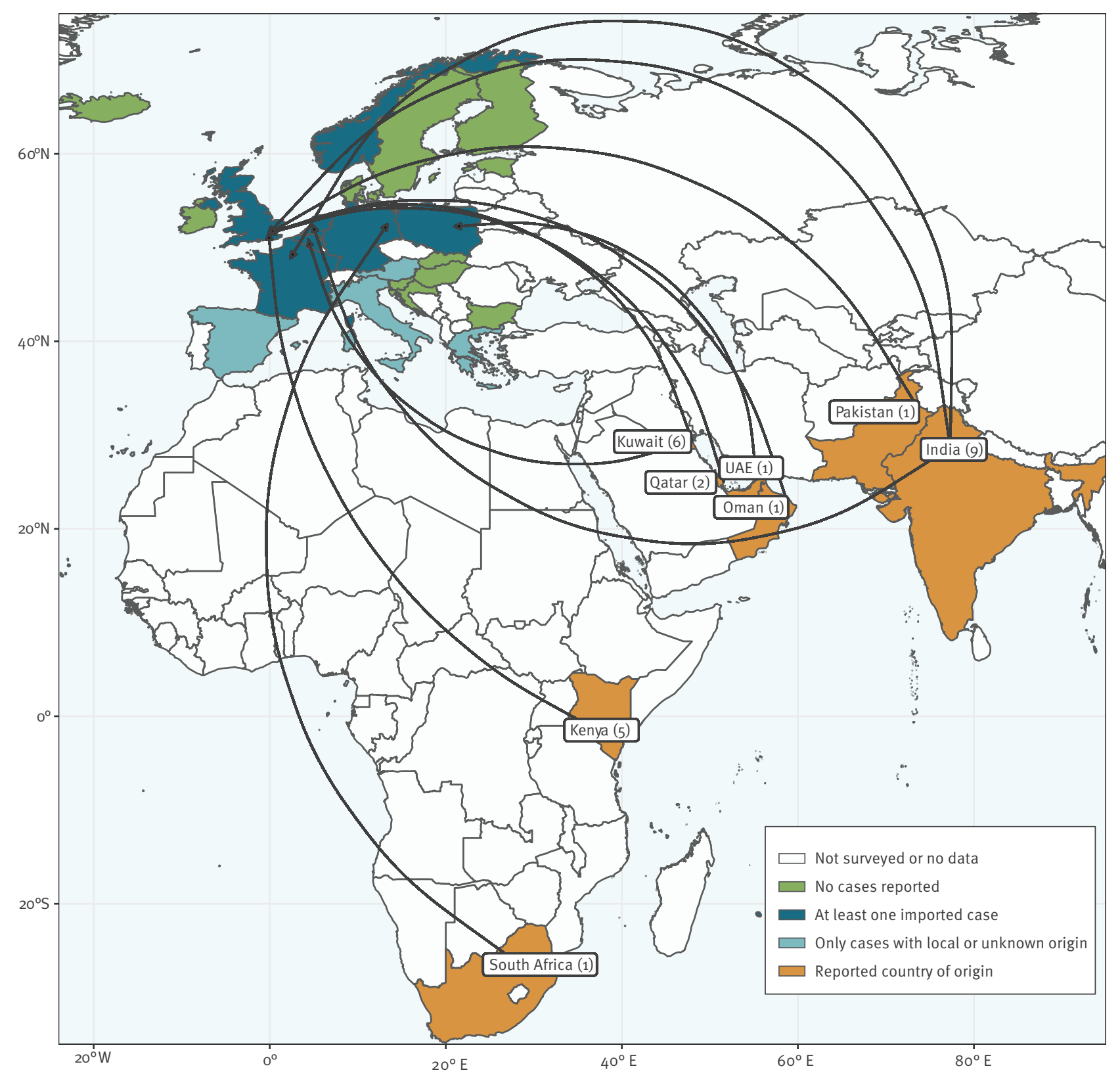

EEA: European Economic Area; EU: European Union.

The number of cases reported as imported into the EU/EEA by probable country of origin is indicated in parentheses

further local transmission. However, information on the investigation of contacts of the sporadic cases is not available and undetected transmission cannot be excluded. Data from the UK show that early detection of outbreaks in combination with isolation, enhanced infection control measures and screening can halt $C$. auris outbreaks [11]. The repeated occurrence of sporadic cases and the detection of cases in countries that were not previously affected underlines the continuous risk of introduction of $C$. auris into hospitals and other healthcare institutions in EU/EEA countries. Five per cent of all reported cases in this survey were classified as imported. Almost half of these cases had previously been hospitalised in India. German authors reported on a case series of seven patients with $C$. auris infection or colonisation. Among these, six had previously been hospitalised in another country: one each in Afghanistan, Dubai, Oman, Russia, Saudi Arabia and the sixth patient was hospitalised in several other countries (Kenya, the UK and the United States) in addition to Germany [12]. This highlights the relevance of screening patients with previous hospitalisation in high prevalence regions for carriage of $C$. auris in addition to multidrug-resistant bacteria. However, a number of cases reported in this survey did not have a history of previous travel or hospitalisation abroad 
National laboratory capacity for Candida auris identification and testing and public health measures taken in response to C. auris, EU/EEA, January 2018-May $2019(\mathrm{n}=29)$

\begin{tabular}{|c|c|c|c|c|c|c|c|c|c|c|}
\hline Country & Notifiable & $\begin{array}{l}\text { Mycology } \\
\text { reference } \\
\text { laboratory } \\
/ \\
\text { laboratory } \\
\text { with } \\
\text { reference } \\
\text { function }\end{array}$ & $\begin{array}{l}\text { Antifungal } \\
\text { susceptibility } \\
\text { testing at } \\
\text { reference } \\
\text { laboratory }\end{array}$ & $\begin{array}{l}\text { Provision of } \\
\text { reference } \\
\text { testing to } \\
\text { hospital } \\
\text { laboratories }\end{array}$ & $\begin{array}{l}\text { Guidance } \\
\text { for } \\
\text { laboratory } \\
\text { testing }\end{array}$ & $\begin{array}{c}\text { Guidance } \\
\text { for } \\
\text { infection } \\
\text { control }\end{array}$ & $\begin{array}{l}\text { Prospective } \\
\text { surveillance }\end{array}$ & $\begin{array}{l}\text { Retrospective } \\
\text { surveillance }\end{array}$ & $\begin{array}{l}\text { Clinical } \\
\text { alert in } \\
2018 \text { a }\end{array}$ & $\begin{array}{l}\text { Laboratory } \\
\text { alert in } \\
2018^{\text {a }}\end{array}$ \\
\hline Austria & $\mathrm{N}$ & $Y$ & $Y$ & $Y$ & $Y$ & $\mathrm{YT}$ & $\mathrm{YT}$ & $Y$ & $Y$ & $Y$ \\
\hline Belgium & $\mathrm{N}$ & $Y$ & $Y$ & $\mathrm{Y}$ & $\mathrm{YT}$ & $\mathrm{Y}$ & $\mathrm{N}$ & $Y$ & $\mathrm{~N}$ & $Y$ \\
\hline Bulgaria & $\mathrm{N}$ & $Y$ & $Y$ & $Y$ & $\mathrm{~N}$ & $\mathrm{~N}$ & $\mathrm{~N}$ & $\mathrm{~N}$ & $\mathrm{~N}$ & $Y$ \\
\hline Croatia & $\mathrm{N}$ & $Y$ & $Y$ & $\mathrm{YT}$ & $\mathrm{N}$ & $Y$ & $Y$ & $\mathrm{~N}$ & $Y$ & $Y$ \\
\hline Cyprus & $\mathrm{N}$ & $\mathrm{N}$ & $\mathrm{N}$ & $\mathrm{N}$ & $\mathrm{N}$ & $\mathrm{N}$ & $\mathrm{N}$ & $\mathrm{N}$ & $\mathrm{N}$ & $\mathrm{N}$ \\
\hline Denmark & $\mathrm{N}$ & $Y$ & $Y$ & $Y^{b}$ & $\mathrm{YT}$ & $\mathrm{N}$ & $Y$ & $Y^{b}$ & $\mathrm{~N}$ & $Y$ \\
\hline Estonia & $\mathrm{N}$ & $\mathrm{N}$ & $\mathrm{N}$ & $\mathrm{N}$ & $\mathrm{YT}$ & $\mathrm{N}^{\mathrm{c}}$ & $\mathrm{N}$ & $\mathrm{N}$ & $Y$ & $\mathrm{~N}$ \\
\hline Finland & $Y$ & $Y$ & $Y$ & $\mathrm{YT}$ & $Y$ & $\mathrm{Y}$ & $\mathrm{Y}$ & $\mathrm{N}$ & $Y$ & $Y$ \\
\hline France & $Y$ & $Y$ & $Y$ & $\mathrm{Y}$ & $\mathrm{YT}$ & $\mathrm{YT}$ & $Y$ & $Y$ & $Y$ & $Y$ \\
\hline Germany & $\mathrm{N}$ & $Y$ & $Y$ & $Y$ & $Y$ & $\mathrm{Y}$ & $\mathrm{N}:$ & $\mathrm{N}$ & $\mathrm{N}$ & $Y$ \\
\hline Greece & $Y$ & $Y$ & $Y$ & $Y$ & $\mathrm{YT}$ & $\mathrm{YT}$ & $\mathrm{YT}$ & $Y$ & $Y$ & $Y$ \\
\hline Hungary & $\mathrm{N}$ & $Y$ & $\mathrm{Y}$ & $\mathrm{Y}$ & $\mathrm{N}$ & $\mathrm{N}$ & $\mathrm{N}$ & $\mathrm{N}$ & $\mathrm{N}$ & $\mathrm{N}$ \\
\hline Iceland & $\mathrm{N}$ & $Y$ & $Y$ & $Y$ & $\mathrm{~N}$ & $\mathrm{~N}$ & $\mathrm{~N}$ & $\mathrm{~N}$ & $\mathrm{~N}$ & $\mathrm{~N}$ \\
\hline Ireland & $Y$ & $\mathrm{~N}$ & $\mathrm{~N}$ & $\mathrm{~N}^{\mathrm{d}}$ & $\mathrm{N}$ & $\mathrm{N}$ & $Y$ & $\mathrm{~N}$ & $Y$ & $\mathrm{~N}$ \\
\hline Italy & $Y$ & $\mathrm{~N}$ & $\mathrm{~N}$ & $\mathrm{~N}$ & $\mathrm{~N}$ & $\mathrm{~N}$ & $\mathrm{~N}$ & $\mathrm{~N}$ & $Y$ & $Y$ \\
\hline Latvia & $\mathrm{N}$ & $\mathrm{N}$ & $\mathrm{N}$ & $\mathrm{N}$ & $\mathrm{N}$ & $\mathrm{N}$ & $\mathrm{N}$ & $\mathrm{N}$ & $\mathrm{N}$ & $\mathrm{N}$ \\
\hline Lithuania & $\mathrm{N}$ & $Y$ & $Y$ & $\mathrm{~N}$ & $\mathrm{~N}$ & $\mathrm{~N}$ & $\mathrm{~N}$ & $\mathrm{~N}$ & $\mathrm{~N}$ & $\mathrm{~N}$ \\
\hline Luxembourg & $\mathrm{N}$ & $Y$ & $\mathrm{~N}$ & $\mathrm{Y}$ & $\mathrm{N}$ & $\mathrm{N}$ & $\mathrm{N}$ & $\mathrm{N}$ & $\mathrm{N}$ & $\mathrm{N}$ \\
\hline Malta & $\mathrm{N}$ & $Y$ & $Y$ & $\mathrm{YT}$ & $\mathrm{N}$ & $\mathrm{N}$ & $\mathrm{N}$ & $\mathrm{N}$ & $\mathrm{N}$ & $Y$ \\
\hline Netherlands & $\mathrm{N}$ & $Y$ & $Y$ & $\mathrm{~N}$ & $\mathrm{YT}$ & $\mathrm{N}$ & $\mathrm{N}$ & $Y$ & $Y$ & $Y$ \\
\hline Norway & $\mathrm{N}$ & $Y$ & $Y$ & $\mathrm{YT}$ & $Y$ & $\mathrm{~N}$ & $\mathrm{~N}$ & $\mathrm{~N}$ & $\mathrm{~N}$ & $Y$ \\
\hline Poland & $\mathrm{N}$ & $\mathrm{N}$ & $\mathrm{N}$ & $\mathrm{N}$ & $\mathrm{N}$ & $\mathrm{N}$ & $\mathrm{N}$ & $\mathrm{N}$ & $\mathrm{N}$ & $\mathrm{N}$ \\
\hline Portugal & $\mathrm{N}$ & $Y$ & $Y$ & $\mathrm{Y}$ & $\mathrm{Y}$ & $\mathrm{YT}$ & $\mathrm{YT}$ & $\mathrm{YT}$ & $\mathrm{N}$ & $Y$ \\
\hline Romania & $\mathrm{N}$ & $\mathrm{N}$ & $\mathrm{N}$ & $\mathrm{N}$ & $\mathrm{N}$ & $\mathrm{N}$ & $\mathrm{N}$ & $\mathrm{N}$ & $\mathrm{N}$ & $\mathrm{N}$ \\
\hline Slovakia & $\mathrm{N}$ & $\mathrm{YT}$ & $Y$ & $\mathrm{~N}$ & $\mathrm{~N}$ & $\mathrm{~N}$ & $\mathrm{~N}$ & $\mathrm{~N}$ & $\mathrm{~N}$ & $\mathrm{~N}$ \\
\hline Slovenia & $\mathrm{N}$ & $Y$ & $Y$ & $Y$ & $\mathrm{Y}$ & $\mathrm{Y}$ & $Y$ & $\mathrm{~N}$ & $\mathrm{~N}$ & $Y$ \\
\hline Spain & $\mathrm{N}$ & $Y$ & $Y$ & $Y$ & $\mathrm{~N}$ & $\mathrm{YT}$ & $\mathrm{N}$ & $\mathrm{N}$ & $Y$ & $Y$ \\
\hline Sweden & $\mathrm{N}$ & $Y$ & $Y$ & $Y$ & $\mathrm{~N}$ & $\mathrm{~N}$ & $\mathrm{~N}$ & $\mathrm{~N}$ & $Y$ & $Y$ \\
\hline $\begin{array}{l}\text { United } \\
\text { Kingdom }\end{array}$ & $\mathrm{N}$ & $Y$ & $Y$ & $Y$ & $Y$ & $Y$ & $Y$ & $Y$ & $\mathrm{~N}$ & $\mathrm{~N}$ \\
\hline
\end{tabular}

EEA: European Economic Area; EU: European Union; N: no; Y: yes.

a Only refers to 2018 and does not include alerts issued in previous years.

${ }^{b}$ Since 2010, all fungal bloodstream isolates in Denmark have been sent to the reference laboratory as part of the national fungaemia surveillance programme. From 2004 to 2009 , only two thirds of the country was covered by this surveillance programme.

'Candida auris is addressed in general infection control guidelines.

${ }^{d}$ Advice for samples to be sent to the United Kingdom for reference testing.

Changes as compared with the previous survey that assessed the situation as at January 2018 are marked with " (no to yes) or .J. (yes to no).

nor were linked to known clusters. The identification of such cases may be an indication of undetected dissemination and is a cause for concern. Furthermore, international communication is crucial, using, if necessary, the European Early Warning and Response System or the International Health Regulations, in cases where $C$. auris has not been reported from the source institution/ country.
Species identification of $C$. auris can be challenging but is a prerequisite for adequate treatment and effective infection control measures [2,3,13]. Yet, seven EU/EEA countries still reported that a reference laboratory did not exist in their country. Thus, cases of $C$. auris may still be misidentified, with the potential to spread in healthcare settings. A survey in April 2018 in Belgium and Luxembourg, only $57.7 \%$ of 142 laboratories were able to correctly identify a strain of C. auris [14], whereas in Germany, $85 \%$ of 233 
participating laboratories correctly identified C. auris. Moreover, six participating countries reported, both in the 2018 and the 2019 surveys, not having issued clinical or laboratory alerts on C. auris. On the other hand, provisions are now in place and reference testing is being offered to hospital laboratories in 18 countries compared with 12 in the 2018 survey. Progress has also been made in developing and introducing guidelines. Whereas in the 2018 survey only six countries reported guidance on laboratory testing [1], 13 did so in 2019. Guidance for clinical management is now available in seven EU/EEA countries compared with three in the 2018 survey, and guidance for infection control is now reported from 11 countries in contrast to only three in the 2018 survey. In addition, the number of countries that performed retrospective surveillance at the time of the 2019 survey had increased from six to 10 , whereas only six countries conducted prospective surveillance. Ensuring laboratory capacity and increasing awareness is addressed in the ECDC rapid risk assessment [6].

\section{Conclusion}

Both introduction of $C$. auris from countries outside of the EU/EEA and spread of $C$. auris within EU/EEA countries are ongoing. Although overall laboratory capacities and public health preparedness and response to $C$. auris are improving, not all EU/EEA countries are equally well prepared. A collective commitment in all EU/EEA countries to improve awareness and optimise laboratory capacities, surveillance and infection control is crucial to prevent further spread of $C$. auris in the EU/EEA.

\section{${ }^{\star}$ Note}

At the time of writing this article, the United Kingdom was part of the European Union.

\section{Candida auris survey collaborative group}

Austria: Cornelia Lass-Flörl, Robert Muchl, Birgit Willinger; Belgium: Katrien Lagrou; Bulgaria: Ivva Philipova; Croatia: Ana Budimir; Cyprus: Linos Hadjihannas; Denmark: Maiken Cavling Arendrup; Estonia: Pille Märtin; Finland: Outi Lyytikäinen, Jari Jalava; France: Françoise Dromer; Germany: Oliver Kurzai; Greece: Georgia Vrioni, Flora Kontopidou; Hungary: Andrea Kurcz, Judit Zala; Iceland: Gudrun Sigmundsdottir; Ireland: Karen Burns; Italy: Maria Luisa Moro; Latvia: Kate Vulāne; Lithuania: Rolanda Valintèlienė; Luxembourg: Monique Perrin; Malta: Elizabeth Anne Scicluna; the Netherlands: Sabine de Greeff; Norway: Oliver Kacelnik; Poland: Aleksander Deptuła; Portugal: Maria do Rosário Rodrigues; Romania: Roxana Serban; Slovakia: Mária Štefkovičová; Slovenia: Mojca Serdt; Spain: Ana Alastruey-Izquierdo, Pilar Gallego Berciano; Sweden: Sara Byfors, UK: Colin Brown.

\section{Conflict of interest}

None declared.

Authors' contributions
D. Plachouras: Design and implementation of the survey, compilation of information received from individual countries and analysis and interpretation of results, drafting the manuscript; F. Lotsch: analysis and interpretation of the results, drafting the manuscript, A. Kohlenberg: design of the survey, interpretation of results, drafting and reviewing the manuscript. D. L. Monnet: Design of the survey, drafting and reviewing the manuscript

Candida auris survey collaborative group: compilation and analysis of national data from laboratories and surveillance databases, validation of national data included in the manuscript and review of the manuscript.

\section{References}

1. Kohlenberg A, Struelens MJ, Monnet DL, Plachouras DThe Candida Auris Survey Collaborative Group. Candida auris: epidemiological situation, laboratory capacity and preparedness in European Union and European Economic Area countries, 2013 to 2017. Euro Surveill. 2018;23(13):18-00136. https://doi.org/10.2807/1560-7917.ES.2018.23.13.18-00136 PMID: 29616608

2. Jeffery-Smith A, Taori SK, Schelenz S, Jeffery K, Johnson EM, Borman A, et al. Candida auris: a review of the literature. Clin Microbiol Rev. 2017;31(1):e00029-17. https://doi.org/10.1128/ CMR.00029-17 PMID: 29142078

3. Bao JR, Master RN, Azad KN, Schwab DA, Clark RB, Jones RS, et al. Rapid, accurate identification of Candida auris by using a novel matrix-assisted laser desorption ionization-time of flight mass spectrometry (MALDI-TOF MS) database (Library). J Clin Microbiol. 2018;56(4):e01700-17. https://doi.org/10.1128/ JCM.01700-17 PMID: 29367296

4. Armstrong PA, Rivera SM, Escandon P, Caceres DH, Chow N, Stuckey MJ, et al. Hospital-associated multicenter outbreak of emerging fungus Candida auris, Colombia, 2016. Emerg Infect Dis. 2019;25(7). https://doi.org/10.3201/eid2507.180491 PMID: 31211679

5. Lamoth F, Kontoyiannis DP. The Candida auris alert: facts and perspectives. J Infect Dis. 2018;217(4):516-20. https://doi. org/10.1093/infdis/jix597 PMID: 29390110

6. European Centre for Disease Prevention and Control (ECDC). Candida auris in healthcare-settings - Europe, first update. Stockholm: ECDC; 2018. Available from: https://www.ecdc. europa.eu/sites/portal/files/documents/RRA-Candida-aurisEuropean-Union-countries.pdf

7. Welsh RM, Bentz ML, Shams A, Houston H, Lyons A, Rose LJ, et al. Survival, persistence, and isolation of the emerging multidrug-resistant pathogenic yeast Candida auris on a plastic health care surface. J Clin Microbiol. 2017;55(10):2996 3005. https://doi.org/10.1128/JCM.00921-17 PMID: 28747370

8. Crea F, Codda G, Orsi A, Battaglini A, Giacobbe DR, Delfino $E$, et al. Isolation of Candida auris from invasive and noninvasive samples of a patient suffering from vascular disease, Italy, July 2019. Euro Surveill. 2019;24(37):1900549. https:// doi.org/10.2807/1560-7917.ES.2019.24.37.1900549 PMID: 31530343

9. Riat A, Neofytos D, Coste A, Harbarth S, Bizzini A, Grandbastien B, et al. First case of Candida auris in Switzerland: discussion about preventive strategies. Swiss Med Wkly. 2018;148:W14622. PMID: 29698547

10. Barantsevich NE, Orlova OE, Shlyakhto EV, Johnson EM, Woodford N, Lass-Floerl C, et al. Emergence of Candida auris in Russia. J Hosp Infect. 2019;102(4):445-8. https://doi. org/10.1016/j.jhin.2019.02.021 PMID: 30851375

11. Public Health England (PHE). English Surveillance Programme for Antimicrobial Utilisation and Resistance (ESPAUR). London: PHE; 2019. Available from: https://www.gov.uk/government/ publications/english-surveillance-programme-antimicrobialutilisation-and-resistance-espaur-report

12. Hamprecht A, Barber AE, Mellinghoff SC, Thelen P, Walther G, Yu Y, et al. Candida auris in Germany and previous exposure to foreign healthcare. Emerg Infect Dis. 2019;25(9):1763-5. https://doi.org/10.3201/eid2509.190262 PMID: 31223105

13. Spivak ES, Hanson KE. Candida auris: an emerging fungal pathogen. J Clin Microbiol. 2018;56(2):e01588-17. https://doi. org/10.1128/JCM.01588-17 PMID: 29167291

14. Dewaele K, Lagrou K, Frans J, Hayette MP, Vernelen K. Hospital laboratory survey for identification of Candida auris in Belgium. J Fungi (Basel). 2019;5(3):E84. https://doi. org/10.3390/jof5030084 PMID: 31491950 
License, supplementary material and copyright

This is an open-access article distributed under the terms of the Creative Commons Attribution (CC BY 4.0) Licence. You may share and adapt the material, but must give appropriate credit to the source, provide a link to the licence and indicate if changes were made.

Any supplementary material referenced in the article can be found in the online version.

This article is copyright of the authors or their affiliated institutions, 2020. 